This article was downloaded by: [Universita Studi la Sapienza]

On: 04 November 2014, At: 01: 19

Publisher: Taylor \& Francis

Informa Ltd Registered in England and Wales Registered Number: 1072954 Registered office: Mortimer House, 37-41 Mortimer Street, London W1T 3J H, UK

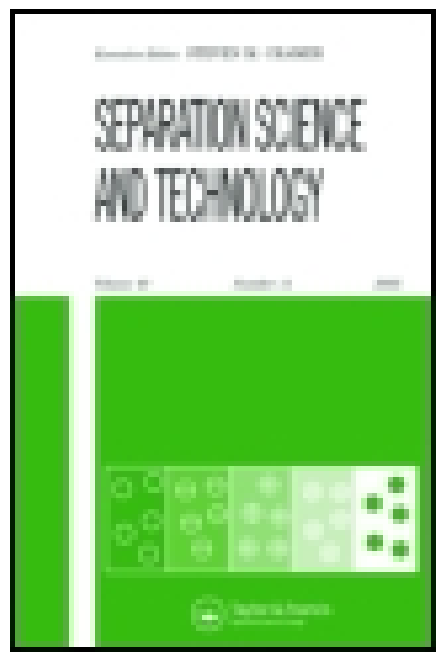

\title{
Separation Science and Technology
}

Publication details, including instructions for authors and subscription information:

http:// www.tandfonline.com/loi/ Isst20

\section{Dyes Adsorption from Aqueous Solutions by Chitosan}

\author{
Loris Pietrelli ${ }^{a}$, Iolanda Francolini ${ }^{b} \&$ Antonella Piozzi ${ }^{b}$ \\ a ENEA-UTTAMB, Via Anguillarese, 301 - 00100 Rome Italy \\ ${ }^{b}$ Department of Chemistry, Sapienza University of Rome, Rome Italy \\ Accepted author version posted online: 28 Oct 2014.
}

To cite this article: Loris Pietrelli, Iolanda Francolini \& Antonella Piozzi (2014): Dyes Adsorption from Aqueous Solutions by Chitosan, Separation Science and Technology, DOI: 10.1080/01496395.2014.964632

To link to this article: http:// dx.doi.org/ 10.1080/01496395.2014.964632

Disclaimer: This is a version of an unedited manuscript that has been accepted for publication. As a service to authors and researchers we are providing this version of the accepted manuscript (AM). Copyediting, typesetting, and review of the resulting proof will be undertaken on this manuscript before final publication of the Version of Record (VoR). During production and pre-press, errors may be discovered which could affect the content, and all legal disclaimers that apply to the journal relate to this version also.

\section{PLEASE SCROLL DOWN FOR ARTICLE}

Taylor \& Francis makes every effort to ensure the accuracy of all the information (the "Content") contained in the publications on our platform. However, Taylor \& Francis, our agents, and our licensors make no representations or warranties whatsoever as to the accuracy, completeness, or suitability for any purpose of the Content. Any opinions and views expressed in this publication are the opinions and views of the authors, and are not the views of or endorsed by Taylor \& Francis. The accuracy of the Content should not be relied upon and should be independently verified with primary sources of information. Taylor and Francis shall not be liable for any losses, actions, claims, proceedings, demands, costs, expenses, damages, and other liabilities whatsoever or howsoever caused arising directly or indirectly in connection with, in relation to or arising out of the use of the Content.

This article may be used for research, teaching, and private study purposes. Any substantial or systematic reproduction, redistribution, reselling, loan, sub-licensing, systematic supply, or distribution in any form to anyone is expressly forbidden. Terms \& Conditions of access and use can be found at http:// www.tandfonline.com/page/terms-and-conditions 


\title{
Dyes Adsorption from Aqueous Solutions by Chitosan
}

\author{
Running title: DYES ADSORPTION BY CHITOSAN
}

Loris Pietrelli ${ }^{\circ}$, Iolanda Francolini *, Antonella Piozzi *

${ }^{\left({ }^{\circ}\right.}$ ENEA-UTTAMB, Via Anguillarese, 301 - 00100 Rome Italy

${ }^{(*)}$ Department of Chemistry, Sapienza University of Rome, Rome Italy

\begin{abstract}
In this study the ability of chitosan to remove acid, basic, reactive and direct dyestuffs by adsorption was studied. The effect of several factors influencing dye adsorption such as dye concentration, grain size, $\mathrm{pH}$ and temperature were investigated. Desorption of dyes at different $\mathrm{pH}$ was also examined. It was shown that the adsorption capacities of chitosan were comparatively high for acid and direct dyes and that the adsorption was controlled by the acidity of the solution. The kinetics of adsorption were found to be of pseudo second order. Batch isotherm studies showed that adsorption of dyes from aqueous solution by chitosan was described by the Langmuir equation.
\end{abstract}

Keywords: adsorption, chitosan, dyes, kinetics, textile wastewater

Corresponding author: Loris Pietrelli

e-mail: loris.pietrelli@enea.it

tel.: +39-06-30484362 fax: +390630483220 


\section{INTRODUCTION}

Dyes are widely used in the industry, such as textile, leather, plastics and paper one, to color the final products. Dye producers and users are interested in dye stability therefore dyestuffs always more difficult to degrade after use are being produced. Since many synthetic dye compounds are harmful to human beings, it is important to encourage industries to implement the color removal from wastewater before to discharge it. In particular, textile industries are water intensive because the specific water intake can vary between 95 to $200 \mathrm{~m}^{3} /$ ton of treated fiber material, depending on the type of process used and water efficiency. In dyeing processes 10-15\% of all dyestuffs, corresponding at about $100 \mathrm{~kg} \mathrm{COD} /$ ton of treated fiber material, is being lost to wastewater and this material, or his degradation products, can be discharged in the environment with visual and environmental strong impact. Many dyes are toxic and some of them, such as those based on benzidine or arylamine are well known for their carcinogenity. A policy for rational use of water resources would allocate the pure water sources for direct human consumption and promote the development of effluent recycling processes to produce water for industrial application for which quality requirements are less stringent (e.g. softening is not necessary for all washing cycles). Among several chemical and physical methods, the adsorption

process, either on activated carbon (1), fly ash (2) or chitin (3), is one of the most effective method to remove dyes from wastewater.

Chitosan appears to be economically attractive due to its origin. It is obtained, on industrial scale, by the alkaline deacetylation of chitin, the second most abundant polymer in nature after to cellulose (4). The main commercial sources of chitin are waste materials of the seafood industry, 
mainly shell of crab and shrimp, that are treated with aqueous sodium hydroxide solutions (40$50 \%$ ) at about $110^{\circ} \mathrm{C}$.

One of the most interesting advantages of chitosan is its versatility. Indeed, this material can be readily modified preparing different polymer form such as beads (5), membranes (6), sponges (7). Other useful features of chitosan include non-toxicity, hydro-philicity, biocompatibility, biodegradability and anti-bacterial property (8) and currently it finds application in the industrial wastewater treatment and in the recovery of materials feed-grade from food-processing plants. Chitosan is effective material for sorption of metal ions and organic compounds such as phenols, polychlorinated biphenyls and proteins. This property is due to the amino and hydroxyl groups on polymer chains that can serve as coordination and electrostatic interaction sites, respectively (8). Critical reviews of published data about chitosan applications appeared in 2000 (8), 2003 (9) and in 2004 (10). Chitosan is versatile in sorbing metals, surfactants, detergents, etc. therefore can be considered as novel material to facilitate (increasing the size of the dissolved component) the treatment by membrane of wastewater (polymer enhanced filtration) and it also may provide new applications water treatment such as Boron (11) and Cyanotoxins (12) removal.

Chitosan has an extremely high affinity for many classes of dyes, except for basic dyes and it has a greater adsorption capacity compared to other poor materials. Therefore, chitosan appears to be economically attractive, more than activated carbon for dye removal from wastewater.

The equilibrium analysis is the most important study required for evaluating the affinity of a sorbent towards a reagent. Therefore, to assess chitosan suitability for application in the field of 
textile wastewater treatment, in this study the ability of chitosan to remove acid, basic, reactive and direct dyestuffs by adsorption was studied.

\section{MATERIALS AND METHODS}

Chitosan (molecular weight: 400k, grain size: $66.9 \%<40$ mesh, degree of deacetylation: $84-$ 86\% \%) was supplied by Fluka while the commercial grade dyes were purchased from Dyestar and Chimica Tessile producers and used as received. The chitosan surface area (Quantachrome Nova 2200 surface area analyzer) obtained by the nitrogen adsorption method (BET), was 1.578

$\mathrm{m}^{2} / \mathrm{g}$. The water content of this commercial chitosan determined by thermogravimetric analysis (TGA, Mettler Toledo TGA1) was $12,7 \%$ while the decomposition temperature was $292,12{ }^{\circ} \mathrm{C}$. Starting from this chitosan, three grain size fractions $(<0.420 \mathrm{~mm}$, within $0.420 \div 0.707 \mathrm{~mm}$, $>0.707 \mathrm{~mm}$ ) were obtained by sieve shaker in order to study the effect of grain size on the dye adsorption. The main characteristics of the dyes are reported in Table 1. The concentration of the dye solutions was analysed at a determinate wavelength (see Table 1) according to the calibration curve for each dye. Four different concentrations were prepared for each dye and the absorbance was measured by an UV-Vis spectrophotometer (VARIAN DMS 200). The TOC (Total Organic Carbon) was determined by an high temperature analyser (DC-190 Rosemont Analytical Inc.), anhydrous Dextrose (glucose) was used as TOC standard.

Dye aqueous solutions (100-300 mg/l) were prepared by dissolving the solutes into deionised water (Millipore Milli-Q) without $\mathrm{pH}$ adjustment. To obtain the equilibrium adsorption isotherms, a fixed amount $(100 \mathrm{mg})$ of dry chitosan was placed in a $125 \mathrm{ml}$ flask with the dye 
solution (50 ml), stirred at $200 \mathrm{rpm}$ and kept at $20 \pm 0.5^{\circ} \mathrm{C}$. At fixed time intervals (within 0.511.5 hours $)$, the solution was centrifuged and then an aqueous sample $(0.5 \mathrm{ml})$ was withdrawn to determine the dye concentration.

The amount of adsorbed dye $q_{e}(\mathrm{mg} / \mathrm{g})$ was calculated as follows:

$\mathrm{q}_{\mathrm{e}}=\left(\mathrm{C}_{0}-\mathrm{C}_{\mathrm{e}}\right) \mathrm{V} / \mathrm{W}$

where $\mathrm{C}_{0}$ and $\mathrm{C}_{\mathrm{e}}$ were the initial and equilibrium (or at fixed time) concentrations (mg/l) of dye, respectively and $\mathrm{V}$ the volume of the solution $(\mathrm{ml})$ and $\mathrm{W}$ the weight of chitosan $(\mathrm{mg})$.

The experimental parameters included initial dye concentration, time, temperature, grain size and $\mathrm{pH}$, adjusted by $0.1 \mathrm{M} \mathrm{HCl}$ and $\mathrm{NaOH}$ solutions.

Experiments with real wastewater coming from nylon fiber washing step were performed to verify the chitosan application to textile wastewater (chitosan $=0.6 \mathrm{~g}, \mathrm{~V}=50 \mathrm{ml}, \mathrm{TOC}_{\mathrm{i}}=889 \mathrm{ppm}$, $\mathrm{pH}=8.1, \mathrm{Cl}=725 \mathrm{ppm}, \mathrm{SO}_{4}=192 \mathrm{ppm}$, ionic surfactants $=0.36 \mathrm{ppm}$, non ionic surfactants $=7,09$ ppm).

\section{RESULTS AND DISCUSSION}

\section{Adsorption dynamics}

It is well known that amine sites are the main reactive groups for ion sorption onto chitosan, though also hydroxyl groups (especially in the C-3 position) may contribute to the sorption (10). The dye uptake by chitosan from solutions involves several steps needed for solute transfer from 
the liquid phase to the specific sites inside the chitosan particles (e.g. external diffusion and intraparticle diffusion).

Since the chitosan chains have a large number and distribution of the $-\mathrm{NH}_{2}$ and $-\mathrm{OH}$ groups, the kinetic or mass transfer representation is likely to be global. In order to examine the mechanism of the dyes adsorption several kinetic models are used.

The pseudo-first-order equation described by Lagergren (13) can be rearranged to obtain a linear form:

$\log \left(\mathrm{q}_{\mathrm{e}}-\mathrm{q}_{\mathrm{t}}\right)=\log \mathrm{q}_{\mathrm{e}}-\left(\mathrm{k}_{1} / 2.303\right) \mathrm{t}$

A pseudo-second-order equation based on equilibrium adsorption capacity can be expressed in the following form (14):

$\mathrm{t} / \mathrm{q}_{\mathrm{t}}=\left(1 / \mathrm{k}_{2} \mathrm{q}_{\mathrm{e}}^{2}\right)+\left(1 / \mathrm{q}_{\mathrm{e}}\right) \mathrm{t}$

Where $q_{e}(\mathrm{mg} / \mathrm{g})$ represents the amount of adsorbed dye at equilibrium, $q_{t}(\mathrm{mg} / \mathrm{g})$ is the amount of adsorbed dye at time $\mathrm{t}, \mathrm{k}_{1}\left(\mathrm{~min}^{-1}\right)$ and $\mathrm{k}_{2}\left(\mathrm{~g} \mathrm{mg}^{-1} \min ^{-1}\right)$ are rate constants of pseudo first or pseudo second order kinetic models respectively.

Because the above two equations cannot give information about the adsorption mechanism, the simplified intraparticle diffusion model, according to Weber and Morris (15), was tested:

$\mathrm{q}_{\mathrm{t}}=\mathrm{t}^{1 / 2}$ 
The fitting validity of these models can be checked by the slopes and intercepts of $\log \left(\mathrm{q}_{\mathrm{e}}-\mathrm{q}_{\mathrm{t}}\right) \mathrm{vs} \mathrm{t}$, $\mathrm{t} / \mathrm{q}_{\mathrm{t}} \mathrm{vs} \mathrm{t}$ and $q_{t} \mathrm{vs} \mathrm{t}^{1 / 2}$ from each linear plot.

The results at different dye concentration according to the correlation coefficients $\left(\mathrm{R}^{2}\right)$ and the calculated and experimental adsorption capacity values are shown in Table 2.

The correlation coefficient $\mathrm{R}^{2}$ for the pseudo second order adsorption model was high for the acid dye and its calculated equilibrium adsorption capacity $q_{e, c a l}$ fits rather well with the experimental $q_{t}$ values. These results suggest that a second order mechanism is predominant and that the overall rate of dye adsorption appears to be controlled by a chemisorption mechanism which fits the experimental data slightly better than the pseudo first order model.

The $k_{2}$ values tend to decrease with the increase of dye concentration. Although the adsorption seems to follow the kinetics of the pseudo second-order, it is expected that adsorbent and adsorbate interact with weak forces considering the nature of the adsorbent and of the dyes. This seems also confirmed by the fact that desorption is made possible by simple variation of $\mathrm{pH}$. Although the activation energy is lower than that typical of chemisorption, in other papers the same observations were observed (5). The acid dye adsorption was very fast, the equilibrium times were short and with high adsorption capacity such behavior indicated a good affinity between the acid dye and chitosan. 


\section{Adsorption isotherms}

To determine the maximum adsorption capacity of dyes by chitosan, a study of adsorption isotherm (Figure 1) was carried out, at $\mathrm{pH}=6 \div 7$, by using the common models based on the Langmuir and Freundlich equations:

$$
\begin{aligned}
& \mathrm{q}_{\mathrm{e}}=\mathrm{Q}^{\circ} \mathrm{bC}_{\mathrm{eq}} /\left(1+\mathrm{bC}_{\mathrm{eq}}\right) \quad \text { or, linearized } \quad 1 / \mathrm{qe}=\left(1 / \mathrm{Q}^{\circ} \mathrm{k}_{\mathrm{L}}\right)(1 / \mathrm{Ceq})+1 / \mathrm{Q}^{\circ} \quad \text { (Langmuir) } \\
& \mathrm{q}_{\mathrm{e}}=\mathrm{k}_{\mathrm{F}} \mathrm{C}_{\mathrm{eq}} 1 / \mathrm{n} \quad \text { or, linearized } \quad \log \mathrm{q}_{\mathrm{e}}=\log \mathrm{k}_{\mathrm{F}}+1 / \mathrm{n} \log \mathrm{C}_{\mathrm{eq}}
\end{aligned}
$$

where $q_{e}(\mathrm{mg} / \mathrm{g})$ is the amount at equilibrium of dye on the solid phase calculated using the mass balance, $\mathrm{C}_{\mathrm{eq}}(\mathrm{mg} / \mathrm{L})$ is the equilibrium concentration of dye in the aqueous phase. In addition, in Langmuir expression, $\mathrm{Q}^{\circ}(\mathrm{mg} / \mathrm{g})$ corresponds to available sites for complete coverage or to limiting adsorption capacity when the surface is fully covered with dye molecules while $\mathrm{k}_{\mathrm{L}}$ is the Langmuir coefficient related to the affinity of the binding sites (16).

In Freundlich empirical equation, $\mathrm{k}_{\mathrm{F}}$ and $\mathrm{l} / \mathrm{n}$ are empirical constants, determined by intercept and slope of the Freundlich equation in a logarithmic plot, representing the adsorption capacity and intensity, respectively.

The essential characteristics of the Langmuir equation can be expressed in terms of a dimensionless separation factor $\mathrm{R}_{\mathrm{L}}$ which is defined by McKay (17) as:

$\mathrm{R}_{\mathrm{L}}=1 /\left[1+\left(\mathrm{k}_{\mathrm{L}} \mathrm{C}_{\mathrm{o}}\right)\right]$ 
where $C_{o}$ is the highest initial dye concentration $(\mathrm{mg} / \mathrm{ml})$. $\mathrm{R}_{\mathrm{L}}$ indicates the shape of the isotherm and the adsorption is unfavourable if $\mathrm{R}_{\mathrm{L}}>1$, favourable if $0<\mathrm{R}_{\mathrm{L}}<1$, irreversible if $\mathrm{R}_{\mathrm{L}}=0$ and linear if $R_{L}=1$. In Table 3, the calculated separation factor values are reported for each dye. The low $R_{L}$ values seem to confirm the high affinity between chitosan and all the tested dyes.

It was observed that the adsorption capacity $\left(\mathrm{q}_{\mathrm{e}}\right)$, defined as the adsorbed dye amount at the isotherm plateau, depended on the nature of the dye. Under the same experimental conditions, the adsorption capacity decreased in the order Acid $>$ Direct $>$ Reactive $>$ Basic dye, as reported in Table 3. This adsorption capacity is significantly greater than those obtained previously using adsorbent such as carbon (18), clay-carbon mixture (14), fly ash (2) and chitin (3).

The reactive dye $q_{e}$ value, lower than acid and direct dye ones, could be explained by probable intramolecular interactions establishing between the $\mathrm{SO}_{3}{ }^{-}$and $\mathrm{NH}_{2}$ groups, both positioned in the same benzenic ring of the dye (Figure in table 1). For this reason, the dye $\mathrm{SO}_{3}{ }^{-}$groups seem to have low effectiveness in electrostatic interaction with $\mathrm{NH}_{3}{ }^{+}$groups of chitosan (19).

Therefore, the reactive dyes tend to react with the primary hydroxyl groups of chitosan as demonstrated by Gardner \& Purves (20) for cellulose.

\section{Effect of initial dye concentration}

Figure 2 shows the effect of initial dye concentration on the adsorption kinetics of chitosan at $20^{\circ} \mathrm{C}$. An increase in initial dye concentration led to an increase in the adsorption capacity of dyes as reported also by other authors $(4,16,21)$, this is due to the increase of driving force of the concentration gradient which promotes the intraparticle diffusion (21). Indeed, a rise in the 
concentration gradient caused a rapid dye diffusion, a high dye adsorption and a longer time to reach the equilibrium. In particular, for $5 \mathrm{~h}$ with initial dye concentration $\geq 300 \mathrm{mg} / \mathrm{l}$, the adsorption capacity were within $2 \div 4$ times greater than at low concentration (about $100 \mathrm{mg} / \mathrm{l}$ ). This indicates that the initial dye concentration played an important role in the adsorption capacity on chitosan as reported by Chiou et al (16).

\section{Grain size effect}

In Figure 3, the effect of grain size on the acid dye is reported. It can be observed that as the particle size decrease, the adsorption of dye increase.. This could be due to the high surface area of these particles that promotes the dye removal from solution in the initial stages of adsorption process. Such phenomenon, reported previously for adsorption of some dyes on chitin, chitosan (22) and Neem sawdust $(3,23)$, is further improved by the ability of the dye molecule to also penetrate into the internal structure of the chitosan.

\section{Effect of pH}

Figure 4 shows the effect of $\mathrm{pH}$ on adsorption of dyes onto chitosan flakes. It can be noted that dye uptake was in acidic and neutral solution much higher than in alkaline one, probably due to the prevalent negative charge of many dyes. Indeed, at low $\mathrm{pH}$ the amine groups of chitosan will be protonated $\left(\mathrm{R}_{-} \mathrm{NH}_{3}{ }^{+}\right)$to form a sort of polycation and then anions or Lewis bases adsorption will be promoted (10). On the contrary, since the free electron doublet of nitrogen is responsible for the cation adsorption, high $\mathrm{pH}$ will favor the adsorption of basic dyes. Since the value of $\mathrm{pK}_{\mathrm{a}}$ of chitosan has been found to be 7.7 (24), a high number of protonated groups can be found even 
at $\mathrm{pH}=6 \div 7$. Therefore, the dye adsorption is due mainly to electrostatic interactions between two counter ions $(25,26)$. The electrostatic interactions can also explain the huge behavior difference between the basic dye and the other ones. Indeed, the Astrazon red dye, having positive $-\mathrm{R}_{4} \mathrm{~N}^{+}$ groups, showed low adsorption onto chitosan.

\section{Effect of temperature}

The adsorption experiments were carried out at various temperature in the range of $283-323^{\circ} \mathrm{K}$. In Table 4 the thermodynamic parameters related to the dye adsorption by chitosan, obtained from the experiments performed at the different temperatures, at $\mathrm{pH} 6$ and with an initial dye concentration of $100 \mathrm{mg} / \mathrm{l}$, are reported. For all dyes, the adsorption activation energies (obtained by the equation: $k=k_{0 \exp }(-\mathrm{Ea} / \mathrm{RT})$ where $k$ is the rate constant of sorption, $k_{0}$ is the temperature independent factor, $\mathrm{Ea}$ is the activation energy of adsorption, $\mathrm{R}$ is the gas constant and $\mathrm{T}$ is the solution temperature) seem to be small $(0.289-36.94 \mathrm{~J} / \mathrm{mol})$ and the adsorption rate not very sensitive to temperature in the studied range. An increase of temperature leads to a slight increase in initial dye adsorption (data not shown). This behavior could be due to swelling effects of chitosan induced by the temperature increase thus enabling the dye ions to penetrate further within the internal chitosan structure indicating that dyes molecules interact with a larger portion of the polymer chain.

The changes in standard Gibbs free energy, standard enthalpy and standard entropy of the adsorption, obtained from the data at different temperature were determined according the following equation: $\Delta G^{\circ}=-\mathrm{RT} \ln K$ where $K$ is the adsorption equilibrium constant (5). $\Delta H$ and $\Delta S$ were calculated according to the van't Hoff plot. The values demonstrated that the dye-chitosan 
interaction is thermodynamically favored. However the data indicated that the chitosan interactions with the basic dye (cationic) are less favorable than those of the other dyes. The values suggest that adsorption of dye onto chitosan is a spontaneous process and that the enthalpic contribution is much larger than that the entropic one.

\section{Dye desorption}

The regeneration of the sorbent is crucially important for keeping the process cost down. Therefore it is desirable to adsorb pollutants and to regenerate the material for many cycles of application. Since in basic solution the positively charged chitosan amino groups are deprotonated, the dye-chitosan electrostatic interactions become weaker and therefore the dye molecules leave the adsorption sites of chitosan allowing the chitosan reuse for several cycles. Therefore, the desorption can be easy obtained by $\mathrm{pH}$ variation as reported in the literature (5).

Table 5 shows the removal percentage (obtained by mass balance) after adsorption onto chitosan of the Direct and Acid dyes at $\mathrm{pH}=10(0.1 \mathrm{M} \mathrm{NaOH})$ and at room temperature. The removal percentage of the charged material is about $55 \%$ for Direct dye and less than $10 \%$ for Acid dye. Higher $\mathrm{pH}$ and temperature could cause dye hydrolysis (5).

In the case of the Direct dye, different cycles of desorption were performed obtaining similar desorbed amount of dye. Chitosan seems to be useful for at least three cycles. This is a confirmation of the reversible deprotonation of chitosan amino groups. 


\section{Treatment of real wastewater}

It is well known that certain additives such as salt and surfactants present in typical wastewater can either accelerate or retard dye adsorption processes. The effect of the typical wastewater contaminants on the discoloration efficiency was determined by using a real wastewater coming from the final washing step of nylon fiber having a $\mathrm{TOC}=889 \mathrm{ppm}$ and $\mathrm{pH}=8.1$ and containing mainly a reactive dye such as Remazol type series.

In Table 6 the dye and TOC removal percentage from real wastewater are reported. Utilizing wastewater, it was not possible to determine which was the contribution of the dye to the value of TOC but it was evident how the presence of other contaminants (stabilizer, detergents, etc.) did not reduce the dye removal. The TOC reduction was less than $40 \%$, that corresponded to 255 $\mathrm{mgTOC} / \mathrm{g}$ of chitosan of which 112 could be attributed to other pollutants.

Also the adsorption kinetics did not seem to be affected by the presence of other pollutants, this may favor the use of chitosan in the filtration process by reducing the cut-off of the membranes with significant cost savings. Moreover, the normal wastewater temperature variations $\left(15-30^{\circ} \mathrm{C}\right)$ did not significantly affect the overall decoloration process.

\section{CONCLUSIONS}

The present study indicate suitability of applying chitosan in programs aimed at removing dyes from textile wastewater. The extreme variability of textile wastewater should be taken into account in the design of any decolorization system using chitosan, because the adsorption 
capacity of chitosan was found to be depended on the nature and chemistry of the dyes as well as experimental conditions such as $\mathrm{pH}$. The maximum dye adsorption followed the order Acid $>$ Direct $>$ Reactive $>$ Basic dye and this is due to the highest reactivity of the acid dye with the protonated amine group of chitosan. For all dye types, the adsorption was optimum at $\mathrm{pH}<8$. The adsorption of all dyes by chitosan was initially rapid (up to 2 hours), particularly for the Acid dye, and then remained constant. For dye adsorption on chitosan, the Langmuir equation gave the best fit over the entire concentration range.

\section{REFERENCES}

1. Choy, K.H.; Porter, J. F.; Mckay, G. (2004) Intraparticle diffusion in single and multicomponent acid dye adsorption from wastewater onto carbon. Chem. Eng. J., 103: 133.

2. Janos, P.; Buchtova, H.; Ryznarova, M. (2003) Sorption of dyes from aqueous solutions onto fly ash. Water Research, 37: 4938.

3. Annadurai, G.; Chellapandian, M.; Vrishnan, R.V (1999) Adsorption of reactive dye on chitin. Env. Monitoring Assessment, 59: 111.

4. Bailey, S.E.; Olin, T.J.; Bricka, R.M; Adrian, D.D. (1999) A review of potentially low cost sorbents for heavy metals. Water Resource, 33: 2469.

5. Chiou, M. S.; Li, H. Y. (2003) Adsorption behavior of reactive dye in aqueous solution on chemical cross-linked chitosan beads. Chemosphere, 50: 1095. 
6. Pietrelli, L.; Xingrong, L. (2004) Chitosan membrane: tool for chromium (III) recovery from aqueous solutions. Annali di Chimica, 94: 389.

7. Ko, J.A.; Kim, B.K.; Park, H.J. (2010) Preparation of Acetylated Chitosan Sponges (Chitin Sponges). J. App. Polym. Sci., 117: 1618.

8. Ravi Kumar, M.N.V. (2000) A review of chitin and chitosan applications. React. Funct. Polym., 46: 1.

9. Babel, S. and Kurniawan, T.A. (2003) Low cost adsorbents for heavy metals uptake from contaminated water: a review. J. Haz. Mat., 97: 219.

10. Guibal, E. (2004) Interaction of metal ions with chitosan-based sorbents: a review. Separation and purification Technology 38: 43.

11. Tagliabue, M.; Reverberi, A.P.; Bagatin, R. (2014) Boron removal from water: needs, challenges and perspectives. J. Cleaner Production 77: 56

12. Tran, D.C.; Duri, S.; Delneri, A.; Franko M., (2013) Chitosan-cellulose composite materials: Preparation, Characterization and application for removal of microcystin. J. Haz. Mat. $252-253: 355$

13. Lagergren, S. (1898) Zur theorie der sagenannten adsorption geloster stoffe. K. Sven. Valenskapsakad. Handl. 24: 1.

14. Ho, L.S.; Chiang, C. (2001) Sorption studies of acid dye by mixed sorbents. Adsorption 7: 139 . 
15. Weber Jr, W.J.; Morris, J.L. (1963) Kinetics of adsorption on carbon from solutions. $J$. Sanit. Eng. Div. Am. Soc. Civ. Eng. 89: 31.

16. Chiou, M. S.; Ho, P.Y.; Li; H. Y. (2003) Adsorption behavior of dye AAVN and RB4 in acid solution on chemically cross-linked chitosan beads. J. Chin. Chem. Eng. 34: 625.

17. McKay, G. (1982) Adsorption of dyestuffs from aqueous solutions with activated carbon I. Equilibrium and batch contact time studies. J. Chem. Tech. Biotech. 32: 759.

18. Malarvizhi, R.; Ho, Y.S. (2010) The influence of $\mathrm{pH}$ and the structure of the dye molecules on adsorption isotherm modeling using activated carbon. Desalination 264: 97.

19. Cestari, A.R.; Vieira, E.; dos Santos, A.G.P.; Mota, J.A.; Almeida, V.P. (2004) Adsorption of anionic dye. J. Colloid Int. Sci. 280:380.

20. Gardner, T.S. and Purves, C.B. (1942) The distribution of acetyl groups in a technical acetone-soluble cellulose acetate. J. Am. Chem. Soc. 64,1539.

21. Cheung, W.H.; Szeto Y.S.; McKay, G.M. (2007) Intraparticle diffusion processes during acid dye adsorption onto chitosan. Bioresource Technology 98: 2897.

22. Annadurai, G.; Ling L. Y.; Lee, J. (2008) Adsorption of reactive dye from an aqueous solution by chitosan: isotherm, kinetic and thermodynamic analysis. J. Haz. Mat. 152: 337

23. Khattri S.D.; Singh M.K. (2000) Color removal from synthetic dye wastewater using a bioadsorbent. Water Air \& Soil Pollution 120: 283. 
24. Muzzarelli R.A. (1977) Chitin, p.184 Pergamon Press, Oxford

25. Stefanich, S.; Delben, F.; Muzzarelli, R.A. (1994) Interaction of soluble chitosan with dyes in water. I. Optical evidence. Carbohydr. Polym. 24: 17.

26. Wong, Y.C.; Szeto, Y.S.; Cheung, W.H.; McKay, G. (2004) Pseudo First order kinetic studies of sorption of acid Dyes onto chitosan. J. Appl. Polym. Sci. 92: 1633. 
TABLE 1 Main characteristics of selected "commercial grade" dyestuffs

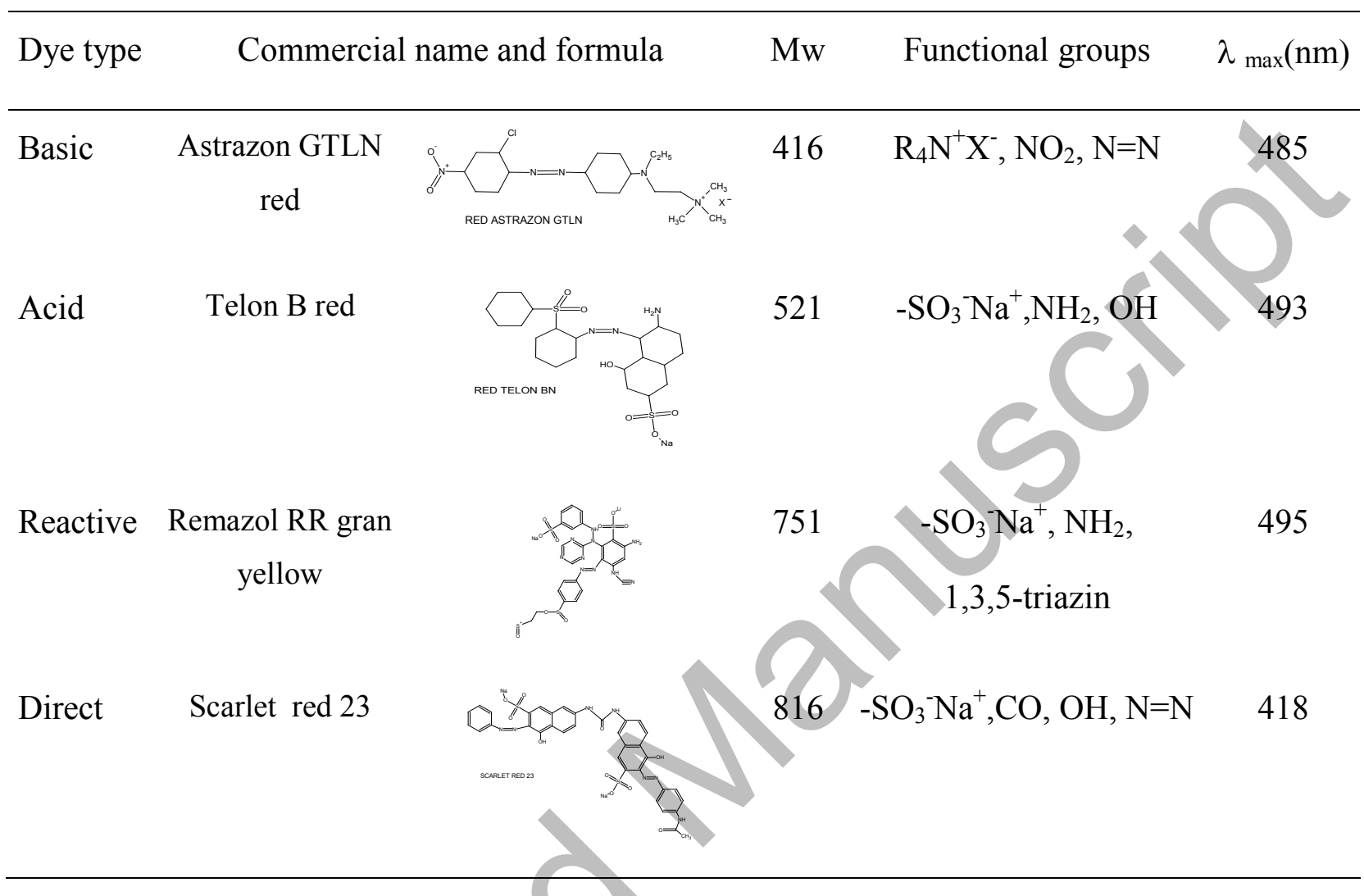


TABLE 2. Values of adsorption rate constants varying dye concentration, $\mathrm{T}=20^{\circ} \mathrm{C}, \mathrm{pH}=6$

\begin{tabular}{|c|c|c|c|c|c|c|c|c|}
\hline \multirow[b]{2}{*}{$\begin{array}{c}\mathbf{C i} \\
(\mathrm{mg} / \mathrm{l})\end{array}$} & \multirow[b]{2}{*}{$\begin{array}{c}\mathbf{q}_{\mathbf{t}} \\
(\mathrm{mg} / \mathrm{g})\end{array}$} & \multicolumn{3}{|c|}{$1^{\text {st }}$ order kinetic model } & \multicolumn{3}{|c|}{$2^{\text {nd }}$ order kinetic model } & \multirow{2}{*}{$\begin{array}{c}\begin{array}{c}\text { Intrap. } \\
\text { diffusion } \\
\text { model }\end{array} \\
\boldsymbol{k}_{\mathrm{i}} \mathbf{R}^{2}\end{array}$} \\
\hline & & $\begin{array}{c}\boldsymbol{k}_{1} \\
\left(\mathrm{~min}^{-1}\right)\end{array}$ & $\begin{array}{c}\mathbf{q}_{\mathrm{e}} \mathbf{c a l} \\
(\mathrm{mg} / \mathrm{g})\end{array}$ & $\mathbf{R}^{2}$ & $\begin{array}{c}\boldsymbol{k}_{\mathbf{2}} \\
(\mathrm{g} / \mathrm{mg} \\
\mathrm{min})\end{array}$ & $\begin{array}{c}\mathbf{h} \\
(\mathrm{mg} / \mathrm{g} \\
\mathrm{min})\end{array}$ & $\begin{array}{c}\text { qecal } \\
(\mathrm{mg} / \mathrm{g})\end{array}$ & \\
\hline
\end{tabular}

\section{Acid dye}

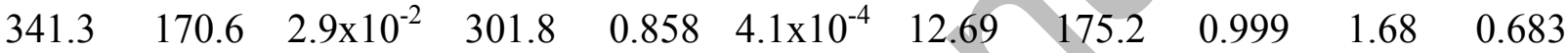

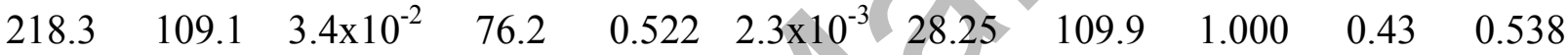

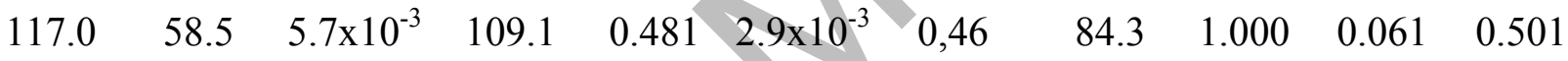

\section{Basic dye}

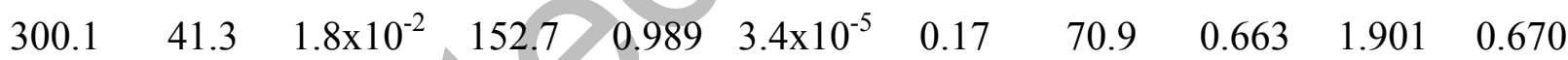

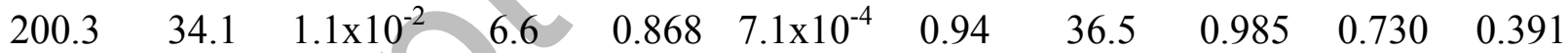

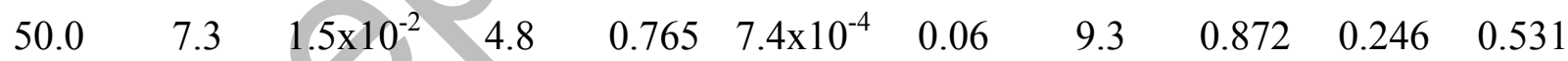

\section{Direct dye}

$\begin{array}{lllllllllll}328.9 & 157.3 & 2.3 \times 10^{-2} & 563.1 & 0.880 & 4.5 \times 10^{-6} & 0.39 & 294.1 & 0.585 & 6.64 & 0.936\end{array}$

$\begin{array}{lllllllllll}187.2 & 86.5 & 1.4 \times 10^{-2} & 366.8 & 0.939 & 3.5 \times 10^{-5} & 0.47 & 116.3 & 0.971 & 3.32 & 0.940\end{array}$

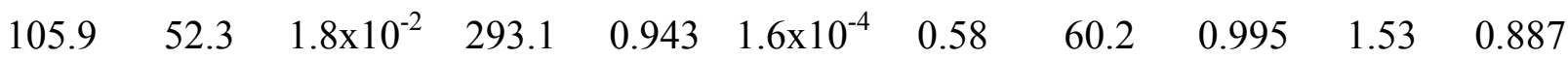




\section{Reactive dye}

\begin{tabular}{llllllllllll}
300.0 & 88.8 & $1.1 \times 10^{-2}$ & 36.7 & 0.241 & $4.5 \times 10^{-4}$ & 3.86 & 92.6 & 0.994 & 1.53 & 0.370 \\
200.0 & 90.6 & $1.8 \times 10^{-2}$ & 165.4 & 0.965 & $2.0 \times 10^{-4}$ & 1.91 & 98.1 & 0.996 & 2.19 & 0.694 \\
100.0 & 50.4 & $1.7 \times 10^{-2}$ & 37.2 & 0.938 & $8.5 \times 10^{-4}$ & 2.31 & 52.4 & 0.999 & 0.74 & 0.664 \\
\hline
\end{tabular}


TABLE 3 Langmuir and Freundlich isotherm parameters at $20^{\circ} \mathrm{C}$

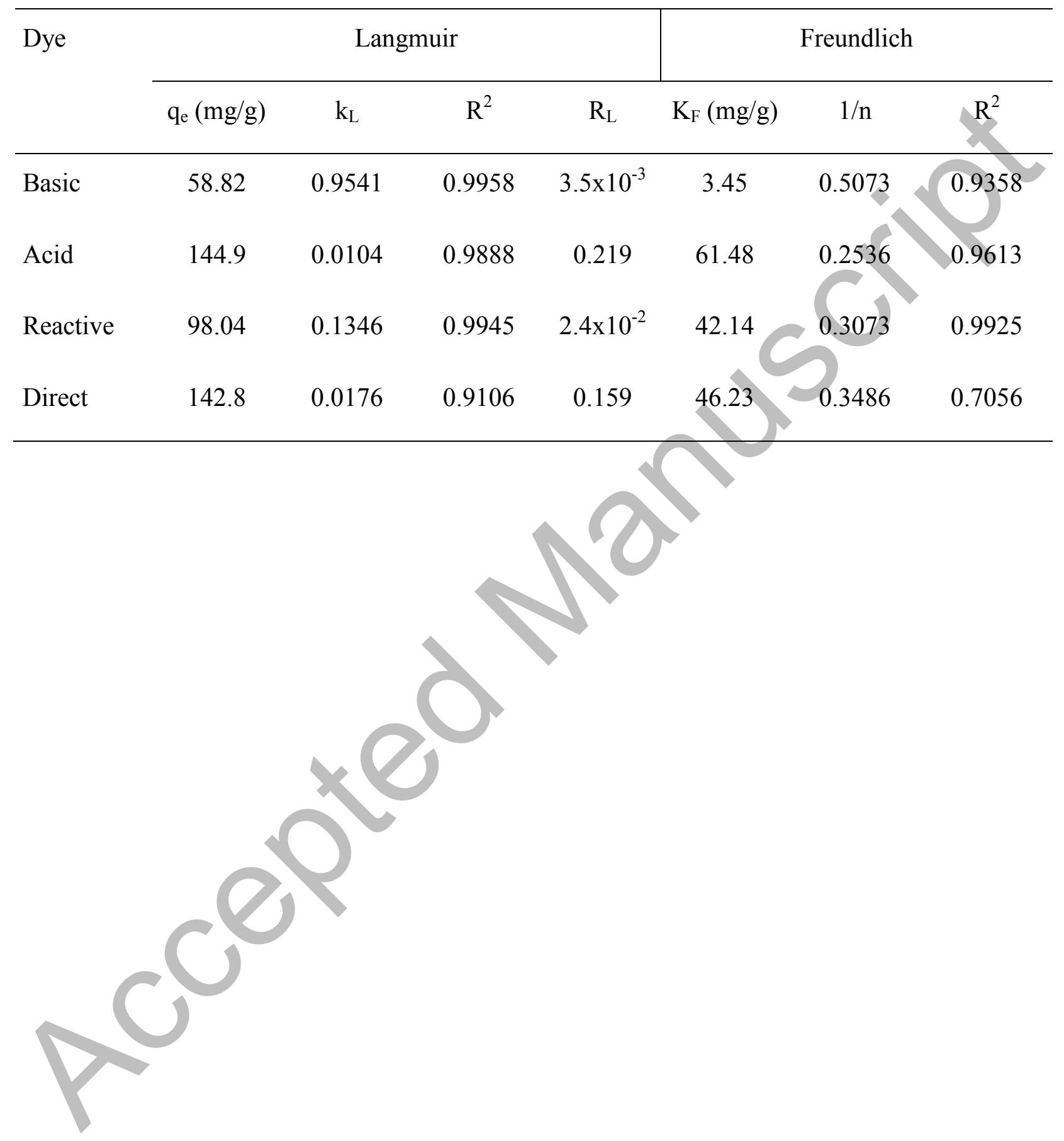


TABLE 4 Activation energies according to the Arrhenius plots, Gibbs energy $\left(\Delta \mathrm{G}^{\circ}=-\mathrm{RT} \ln K\right)$ and van't Hoff plots

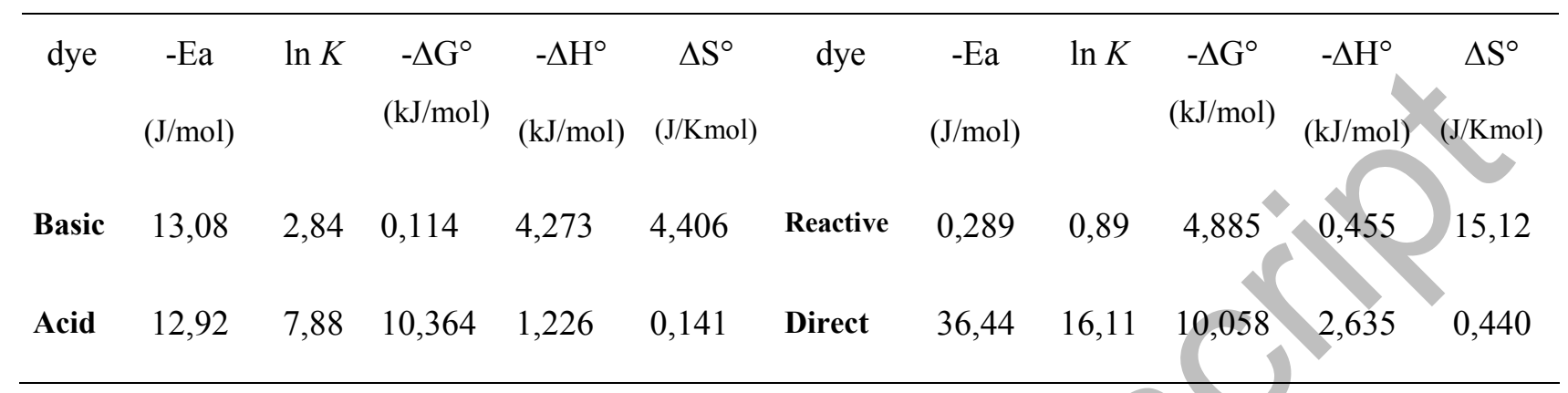


TABLE 5 Desorption experiments (\%) of the Direct (D) and Acid (A) dyes performed at $\mathrm{pH}=10$. Chitosan $=100 \mathrm{mg}$, Dye $=100 \mathrm{mg} / 1$

\begin{tabular}{|c|c|c|c|c|}
\hline Time (min) & I cycle (D) & II cycle (D) & III cycle (D) & I cycle (A) \\
\hline 30 & 45.7 & 36.7 & 26.8 & 8.7 \\
\hline 60 & 52.3 & 46.3 & 39.8 & 8.8 \\
\hline 180 & 54.8 & 48.7 & 45.7 & 8.9 \\
\hline 300 & 54.8 & 50.4 & 48.5 & 9.2 \\
\hline 720 & 54.8 & 51.7 & 49.0 & 9.4 \\
\hline
\end{tabular}


TABLE 6 Dye and TOC removal $\%$ from wastewater. TOC $\mathrm{i}=889 \mathrm{ppm}, \mathrm{V}=50 \mathrm{ml}$, Chitosan $=0.6$ g

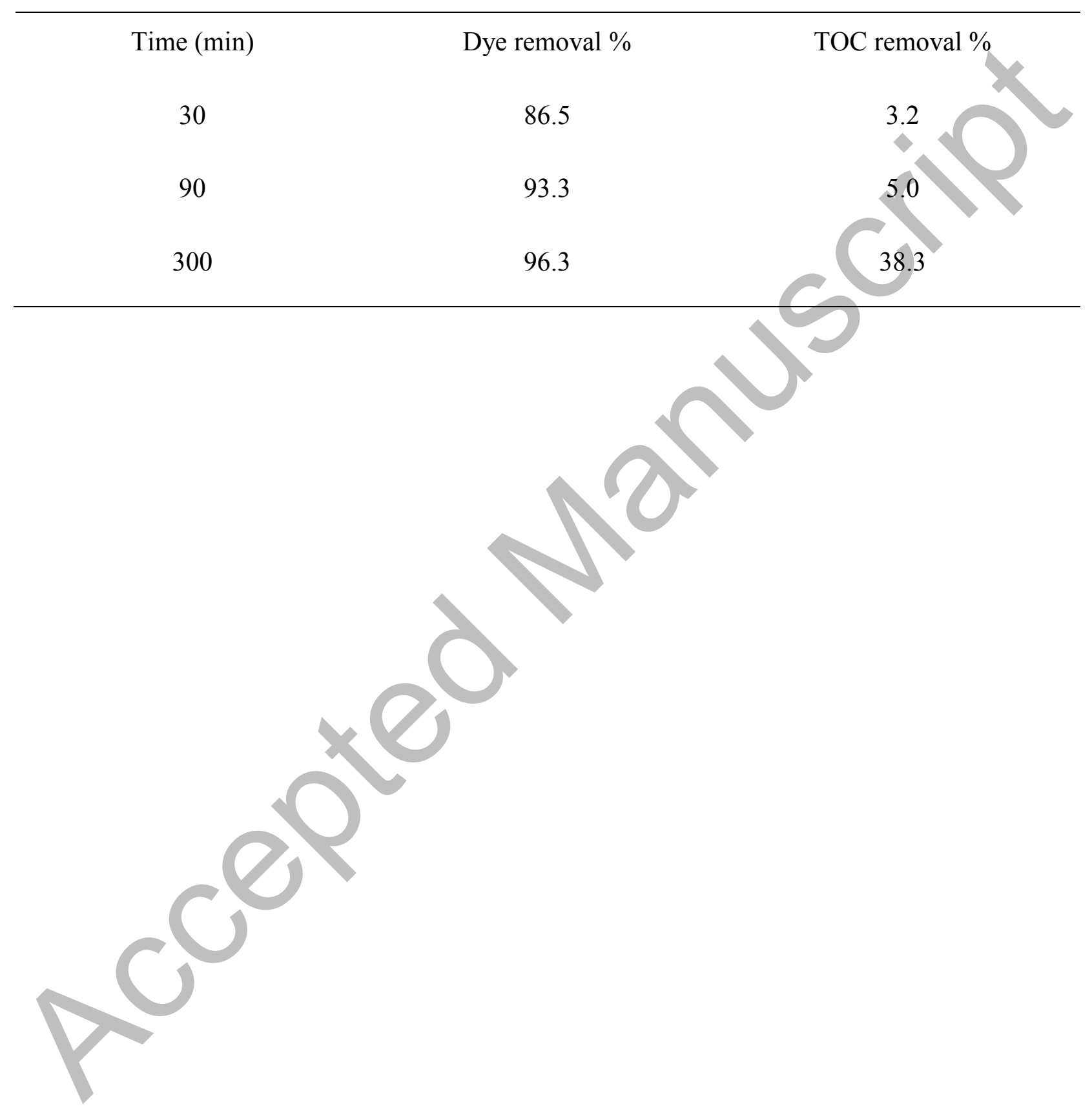


FIG. 1. Adsorption isotherms. V=50 ml, chitosan=100 mg

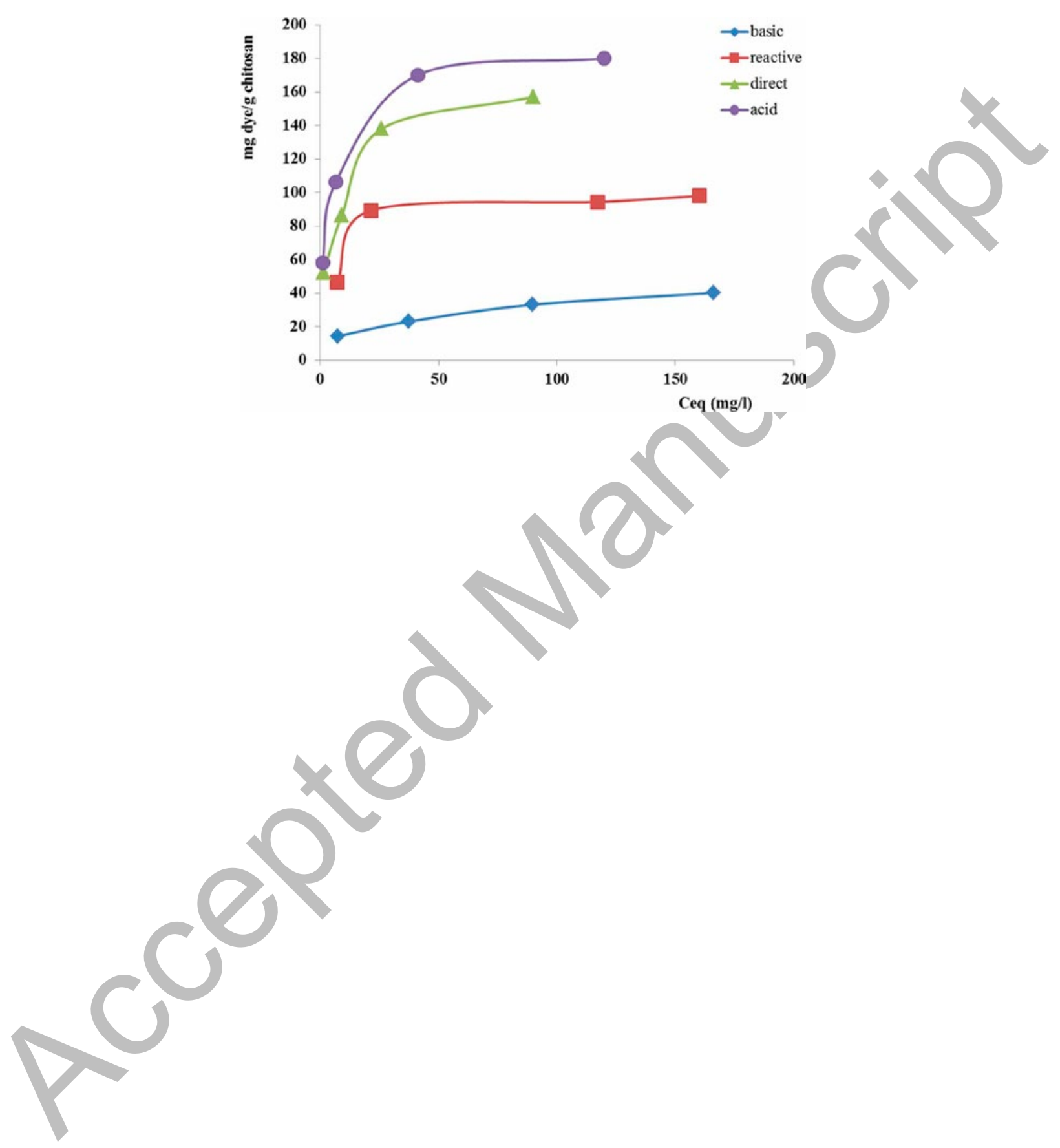


FIG. 2. The effect of initial dye concentration on the adsorption kinetics. V=50 ml, chitosan=100 $\mathrm{mg}$
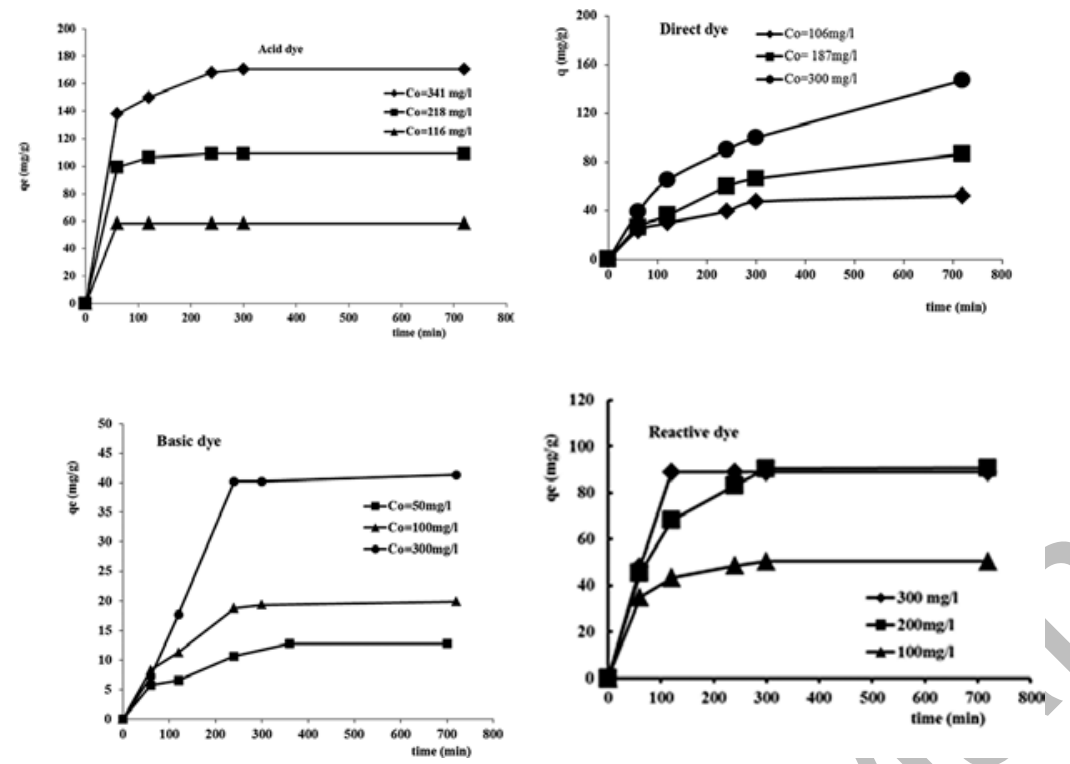
FIG. 3. Grain size effect on Acid dye adsorption. $\mathrm{T}=20^{\circ} \mathrm{C}, \mathrm{C}_{\mathrm{i}}=220 \mathrm{mg} / \mathrm{l}$

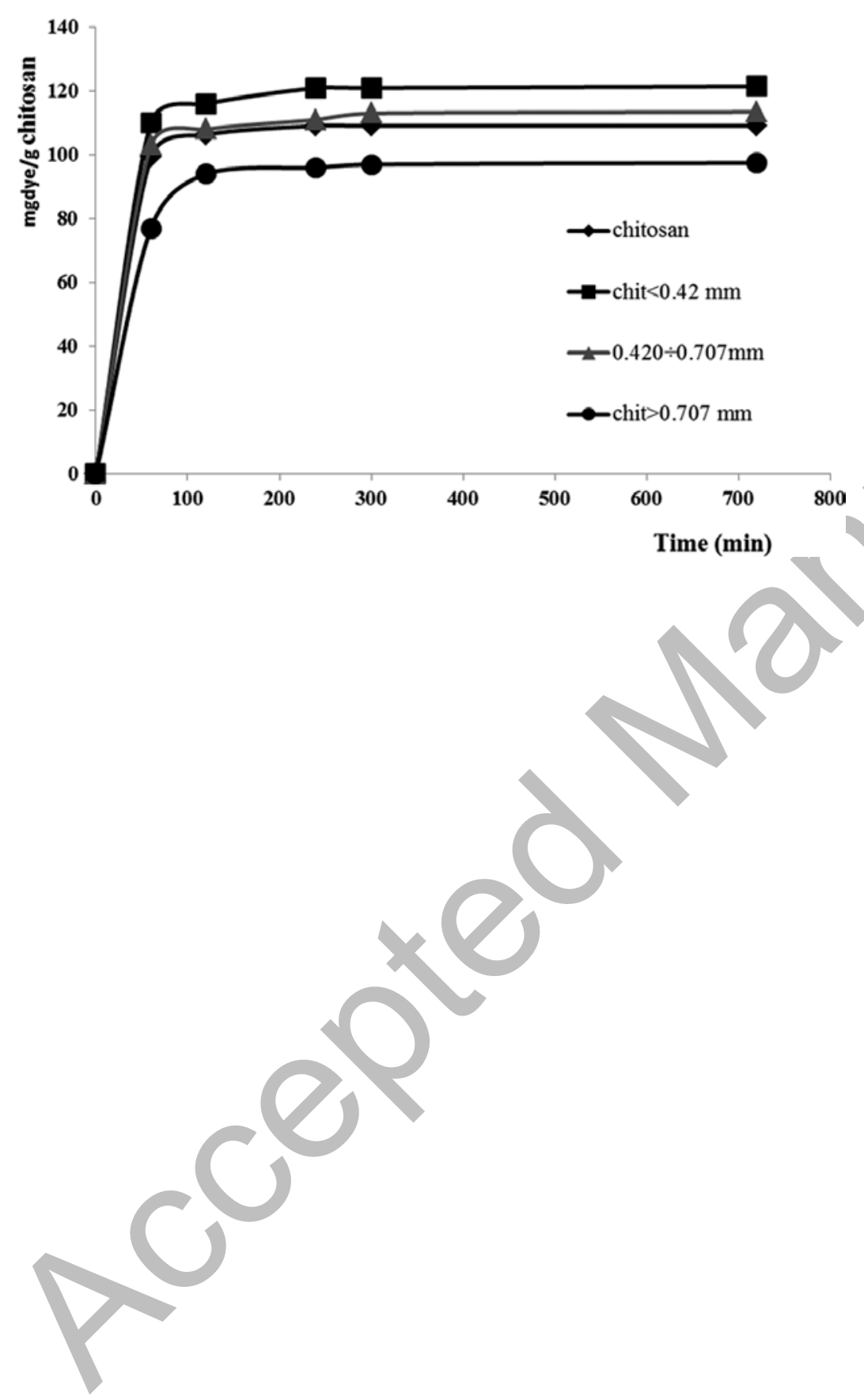


